\title{
Crown competition in the selection forests with the different tree species composition
}

\author{
Jad'ud'J., Saniga M., *Balanda M.
}

Technical University in Zvolen, Department of Silviculture, Faculty of Forestry, T.G. Masaryka 24, 96053 Zvolen, Slovak republic.E-mail:miroslav.balanda@tuzvo.sk

Abstract: Jad'ud' J., Saniga M., Balanda M. 2014: Crown competition in the selection forest with the different tree species composition. - Beskydy, 7 (1): 21-28

The presented paper is oriented on the analysis of interspecific crown competition within the middle and upper layer of the selection forest. The research was conducted in the Norway spruce and silver fir dominated selection forest (demonstration object Donovaly-Mistríky) and in the common beech dominated selection forest in the territory of School Forestry Enterprise of the Technical University in Zvolen, Slovakia. We intended to evaluate the species specific crown-stem relation through the tightness of correlation between the crown volume and the stem volume. Our research confirmed the obvious effect of crown capacity on the production of stem biomass in the selection forest. The analysis revealed significant differences between coniferous and broadleaved species. However the low correlation for both middle and upper layers did not exceed $r^{2}=0.46$ for common beech, the high significant correlations were for spruce and fir $\left(\mathrm{r}^{2}=0.82\right.$ and 0.78 , respectively). There were also significant differences between separated canopy layers. In the middle layer, the crown-stem correlations were lower than in the upper layer, what points out the obvious spatial competitiveness in the middle canopy layer, despite the relatively autonomous position of tree crowns within the canopy.

Keywords: selection forest, common beech, silver fir, Norway spruce, crown-stem relation, competition

\section{Introduction}

The principles of selection forest management are also applicable in such forests, where the species composition is less-typical for creation of selection-forest structure (Yasuda et al. 2011, Schütz and Pommerening 2013).These forest stands are defined by the heterogeneous age structure, at least two-layer vertical structure, and the random distribution of trees. The available growth space is, as a rule, completely occupied by tree crowns and all developmental stages of the age-class forest are presented on the plot (Schütz 1969, 2002, Kucbel, Vencurik 2007). The competition for light takes place usually between neighboring trees of the same tree layer. The temporal development of communities proceeds under the shelter of the oldest canopy trees (Schütz 2002). Within the frame of differentiated vertical structure, the mutual competition between adjacent cohorts lasts only up to the moment when the tree reaches the upper layer (Schütz 1975, 2001a). The canopy tree is characterized by the released crown with the full light income (SснÜтZ 1969). Up to this moment, tree has to endure the suppression of above-standing layers and compete for the light as the limiting factor for its growth and survival (Vencurik, Kucbel 2008, Vencurik et al. 2013). For this reason, the selection-forest concept is mostly connected with the shade-tolerant tree species. The more atypical the recent species composition is, the higher potential losses on the future growing stock are. The researches of natural forest 
of the Europe showed that the selection-forest concept can be applied in the forests dominated by common beech, Norway spruce as well as in the forests with the sufficient proportion of silver fir (Schütz 1969, Saniga et al. 2013). In the selection forest, the vertical competitiveness substantially affects the morphology of tree crowns. Moreover, the capacity of tree crown directly correlates with the volume of tree stem (Saniga, Vencurik 2007). The relation between the stem and crown volume has not yet been investigated in the selection forests. Schütz (2001b) stated that the beech needs from three- to five times more of available growth space than the spruce to create the stem of the same diameter. Taking into account the same crown volume, the radial increment of spruce and fir will reach from fourto five-fold higher values than that of common beech. The different utilization of growth space by spruce crowns in comparison to beech in the same bio-sociological position (classification according to Kraft) was reported by Pretzch et al. (1998). When compared to self-standing spruce, the tree standing in the position of the $4^{\text {th }}$ or the $5^{\text {th }}$ tree class reaches approximately one half of the crown volume of solitaire tree. Similarly, the beech standing in the lower layer is able to create the crown of the several percent of the mean tree crown of canopy. Especially the plagiotropic nature of beech growth is considered to be the disadvantage in achievement of selectionforest structure (Schütz 2002). The natural regeneration of beech requires stronger removal of canopy trees and the maintenance of higher number of recruited individuals. Moreover, the beech regeneration is not able to survive such level of shading as the spruce and fir. The spruce is capable to react on the improvement of light conditions even in the higher physical age. However, the thinner spruce can respond to canopy release more promptly. The harvest of target diameter trees leads to significant differentiation of dendrometrical parameters like stem and crown volume, especially of the codominant trees (Uhl 2009). The fir-admixture tree stands are characterized by the higher productivity potential and the mechanical stability (Utschig 2004). Teufel et al. (2005) considered the fir to be the main tree species of structurally differentiated mountain forests. During the longer time span, the fir produces high increment and it is not as susceptible to abiotic and biotic damage as the spruce. The volume production is directly influenced by the intensity of vertical competitiveness and rate of achieving the autonomous-growth position. Even in the middle layer of selection forest, the fir has more autonomous position than spruce (Jad'ud' 2013).

The main aims of this paper were:

- To research the species-specific relation between the crown volume and the stem volume of tree

- To evaluate the response of spruce and fir to competitive pressure

\section{Material and Methods}

We analyzed the Norway spruce (Picea abies (L.) Karst.), silver fir (Abies alba Mill.) and common beech (Fagus sylvatica L.) trees occupying the middle layer of the selection forest. The spruce-fir data were obtained from demonstration object Donovaly-Mistríky (50.4 ha, N48 ${ }^{\circ}$ $\left.52^{\prime} 26^{\prime \prime} \mathrm{E} 19^{\circ} 14^{\prime} 28^{\prime \prime}\right)$ located in the orographic unit Low Tatras. The elevation of the object is 960-1050 $\mathrm{m}$ asl., the average annual temperature varies in the span $4.2-4.8^{\circ} \mathrm{C}$. From point of view of phytocoenology, it belongs to the $6^{\text {th }}$ forest vegetation zone, the group of forest types Fagetum-abietino-piceosum. The forest stand was dominated by the N. spruce with the admixture of silver fir. In total, we analyzed 214 firs and 462 spruce trees. Measured trees were grown on the permanent research plots (PRP) located in the four forest management units (FMU) with the selection-forest structure (Tab.1). The beechdata were collected from the beech selection forests in the territory of the School Forestry Enterprise of Technical University in Zvolen. Forest stands were located in the elevation of 510-540 $\mathrm{m}$ asl, with the annual precipitation amount of $650-700 \mathrm{~mm}$ and average annual temperature of $6.1-6.4{ }^{\circ} \mathrm{C}$. Overall, 97 trees of beech were measured. All analyzed individuals originated from four permanent research plots (PRP) established in the FMU No. 513 and 514 (Tab.1). The phytocoenosis of Fagetum pauper nst. prevailed on the research plots. Analyzed stands were of $\mathrm{W}$ exposure, with the slope inclination of $10-15 \%$. PRPs were established for the purpose of conversion to selection-forest structure in 1995. Considering to the available knowledge (Dittmar 1990, Gerold and Biehl 1992, Schütz 1992, 2001a) the model of beech selection forest was adjusted to the target diameter of $54 \mathrm{~cm}$ and the target growing stock of $270 \mathrm{~m}^{3} \mathrm{ha}^{-1}$. The beech and spruce were grown in the optimal conditions, while the conditions for the growth of fir were suboptimal.

On each of PRPs, all trees with the stem diameter at the breast height (dbh) over $12 \mathrm{~cm}$ were recorded. We measured the height of tree (m), 
diameter at $1.3 \mathrm{~m}(\mathrm{~m})$, height of crown base (m), and two crown diameters (m).

The crown volume $\left(v_{c}\right)$ was calculated according to JURČA (1968) as follows:

$$
\begin{aligned}
& v_{c}=\frac{\pi}{8} \cdot b^{2} \cdot l \\
& v_{c}=\frac{\pi}{12} \cdot b^{2} \cdot l
\end{aligned}
$$$$
\text { for broadleaved species (1) }
$$$$
\text { for coniferous species }
$$

where: $l$ - crown length $(\mathrm{m})$

$b$ - average crown diameter $(\mathrm{m})$

For each reserve, the dominant height $\left(h_{10 \%}\right)$ was computed as the mean height of the $10 \%$ tallest trees (Šmelko 2000). The dominant height was used to assign each tree to one of three tree layers (lower, middle and upper layer) using the following thresholds: lower layer - trees with height $h<1 / 3 h_{10 \%}$, middle layer $1 / 3 \leq h<2 / 3 h_{10 \%}$, and upper layer $h \geq 2 / 3 h_{10 \%}$.
The volume of each tree was calculated according to the two-parameter (dbh and height) equations derived by Petráš and Pajtík (1991).

The linear function was used to estimate the relation between the crowns and stem volumes. The empirical data were processed using the software Statistica 7.0 (Stat Soft, Inc.).

We regarded the crown volume as the main factor that particularly contributes to the biomass production of the tree stem. For this analysis, we used a one-way ANOVA followed by the Duncan's test to evaluate the statistical significance of differences among the homogenous groups.

\section{Results}

The quantification of assimilatory apparatus through the calculation of crown volumes revealed that the highest values were reached by the common beech growing in the position of upper layer (Fig.1- left).

Tab. 1: The basic production parameters of researched forest stands.

\begin{tabular}{cccccccc}
\hline \multirow{2}{*}{$\begin{array}{c}\text { Management } \\
\text { unit }\end{array}$} & $\begin{array}{c}\text { Stem } \\
\text { density } \\
\left(\text { tree ha }^{-1}\right)\end{array}$ & $\begin{array}{c}\text { Growing stock } \\
\left(\mathbf{m}^{\mathbf{3}} \mathbf{h a}^{-1}\right)\end{array}$ & $\begin{array}{c}\text { Basal area } \\
\left(\mathbf{m}^{\mathbf{2}} \mathbf{h} \mathbf{a}^{-1}\right)\end{array}$ & $\begin{array}{c}\text { Stem } \\
\mathbf{d e n s i t y} \\
\left(\text { tree ha }^{-1}\right)\end{array}$ & $\begin{array}{c}\text { Growing } \\
\text { stock } \\
\left(\mathbf{m}^{\mathbf{3}} \mathbf{h} \mathbf{a}^{-1}\right)\end{array}$ & $\begin{array}{c}\text { Basal area } \\
\left(\mathbf{m}^{\mathbf{2}} \mathbf{h a}^{-1}\right)\end{array}$ & $\begin{array}{c}\text { Target } \\
\mathbf{d b h} \\
(\mathbf{c m})\end{array}$ \\
\hline 606 & 912 & 362.0 & 29.2 & 613 & 324.24 & 30.19 & 66 \\
631 & 640 & 562.3 & 50.8 & 698 & 413.18 & 38.52 & 74 \\
$632 \mathrm{a}$ & 616 & 429.3 & 39.5 & 663 & 301.98 & 28.54 & 70 \\
$632 \mathrm{c}$ & 816 & 365.9 & 36.8 & 613 & 324.24 & 30.19 & 66 \\
513,514 & 639 & 344.2 & 28.1 & 689 & 269.70 & 26.30 & 54 \\
\hline
\end{tabular}
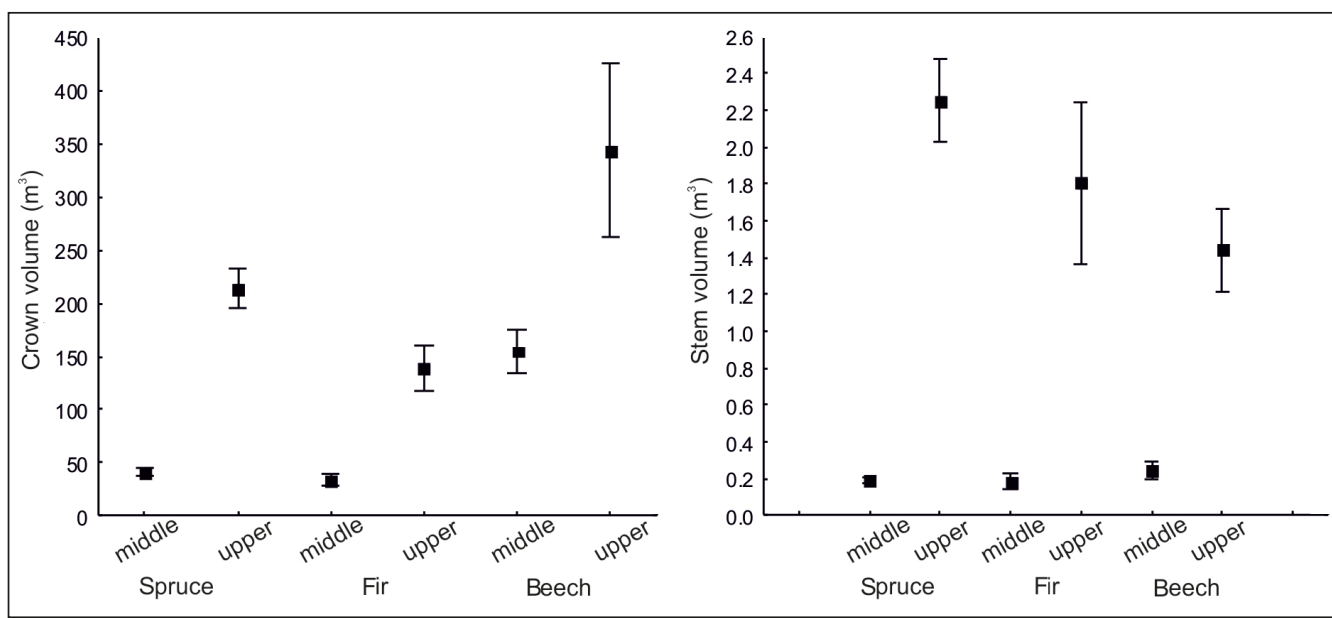

Fig. 1: The mean ( \pm 0.95 confidence interval) crown (left) and stem (right) volume of trees in the selection forest according to tree species and position within canopy layers. 
Likewise, the beech showed the highest difference between the volume of mean crown volume of upper layer trees and those of middle layer. The spruce reached the second highest crown volume from among trees of upper layer. We recorded significant differences between the crown volumes according to tree species and even the tree layers. The exception was the similar crown size of the spruce and fir growing in the middle layer. Furthermore, there was no difference between the crown volume of beech of middle layer and fir from upper layer (Fig.l left). The average volume of stems according to tree species and layers is depicted in the Fig.1 right. There were no significant differences between the stem volumes of trees in middle layer ( $p>0.05)$. Regarding the upper canopy layer, the mean stem volume differed significantly between all three species $(p<0.5)$.

Growth relations between the volumes of stems and crowns are presented in the Fig. 2. The effect of assimilatory capacity expressed by the crown volumes of beech on its stem volume was very heterogeneous. The significant competition of neighboring trees and the unsuitable light conditions in the middle layer yielded in the low correlation between the stem and crown volume of beech $\left(r^{2}=0.15\right)$. In contrast, the correlation in upper layer was slightly higher $\left(r^{2}=0.28\right)$. Regardless of the tree layer, the middle degree of correlation between the crown volume and stem volume of beech was confirmed $\left(R^{2}=0.46\right)$. Therefore, the crown volume of beech contributes to its stem volume only by $46 \%$. High variability of beech crown size in both middle and upper canopy layers was caused by the great morphological plasticity of beech crowns and their ability to respond promptly to abrupt release of growth space. This statement is confirmed by the reaction of stem volume as its increase only slightly correlated with the increase of crown volume.

The relation between the volume of fir stems and its crowns is presented in Fig.3. The linear function showed the medium degree of correlation $\left(r^{2}=0.45\right)$ in the middle layer. The analysis confirmed higher degree of growth autonomy in this layer comparing to other tree species. The competitiveness of neighboring trees was lower when compared to beech. Regarding the growth within the frame of upper layer, a closer relation between evaluated biometric parameters was observed $\left(R^{2}=0.56\right)$. We can found high growth autonomy of fir in the position of upper

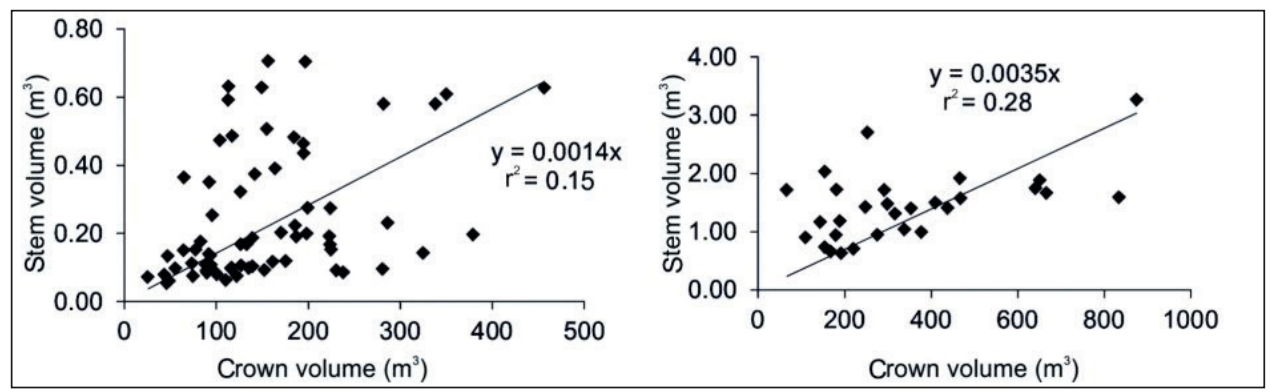

Fig. 2: Relation between the volume of stem and crown volume of common beech according to tree layers (left-middle layer, right-upperlayer).
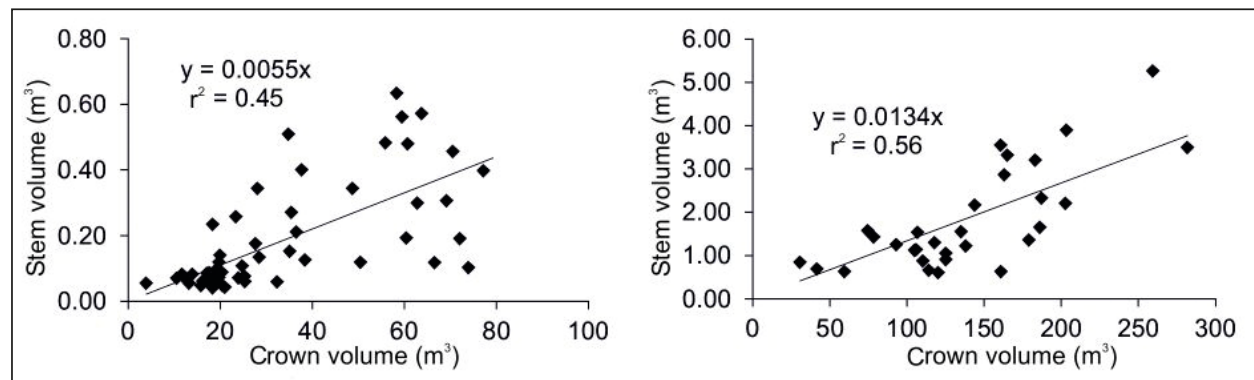

Fig. 3: Relation between the volume of stem and crown volume of silver fir according to tree layers (left-middle layer, right-upperlayer). 


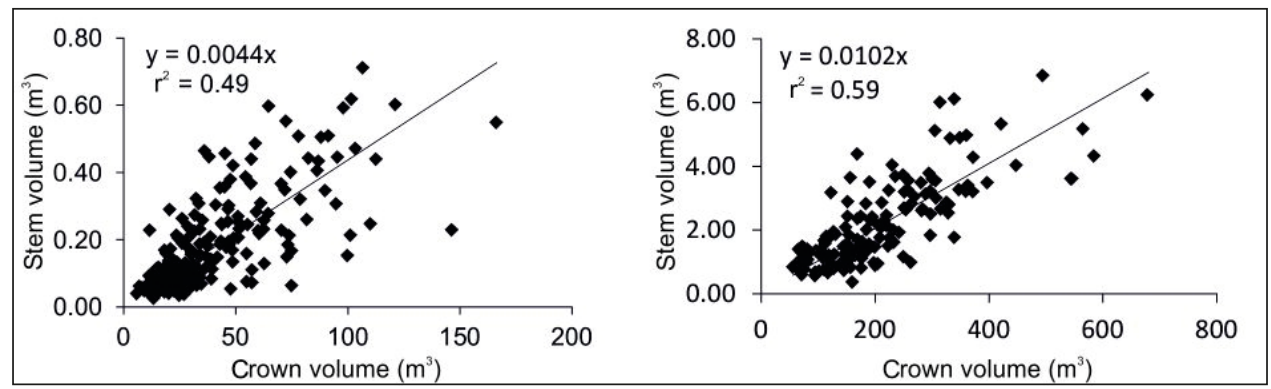

Fig. 4: Relation between the volume of stem and crown volume of Norway spruce according to tree layers (left-middle layer, right-upperlayer).

layer. The crown contributed on stem volume production by $56 \%$. Regardless of the tree position within vertical canopy profile, the analysis discovered close relation between crown volume of fir and its stem volume $\left(r^{2}=0.78\right)$. It was significantly higher when compared to common beech.

The analysis of spruce growth patterns is shown in Fig. 4. In the middle layer, the correlation analysis confirmed the closest relation from among all analyzed tree species. The spruce crown contributes to stem volume production by $49 \%$.

When analyzed the spruce trees of upper layer, the tightness of correlation slightly increased $\left(r^{2}=0.59\right)$. However, the overall analysis regardless the tree position within canopy layer showed very tight correlation between the crown and stem volume $\left(r^{2}=0.82\right)$.

Our research confirmed the less intensive impact of competition on the spruce crowns when compared to fir. The volume of beech crown showed the highest variability, the most probably due to its morphological plasticity. We can conclude that the beech was able to promptly increase the capacity of its crown when the abrupt release of growth space; however it did not affect the production of growing stock so much like the expansion of fir or spruce crowns.

\section{Discussion}

The production patterns of coniferous and broadleaved selection forests on the plots of the Swiss Research Institute WSL had been researched by Badoux (1949). For the purposes of the modelling of stand increment, a crown volume can be regarded as the most suitable feature expressing the performance of assimilatory apparatus (Pretzch 2010). The crown volume as the parameter of the growth space utilization directly depends on the competition of adjacent trees. Crown volume decreases proportionally to declining sociological position of tree (Pretzch et al. 1998). Analogous to results of Saniga and Vencurik (2007), also our research confirmed the obvious effect of crown capacity on the production of stem biomass in the selection forest. Common beech showed the lowest degree of correlation $\left(r^{2}=0.46\right)$. This confirms the well-known tendency of beech to plagiotropic growth. We observed rather high variation of crown volumes of all analyzed tree species in the middle layer. The growth space in the selection forest is characterized by higher heterogeneity of growth conditions which are directly determined by performed silvicultural treatments. The single-tree oriented selective cutting is of great importance for the gradation of biomass production (Leibundgut 1945). According to Schütz (2002), the lateral competition does not take place within the vertical profile of selection forest with exception of its lower layer. Trees are losing the direct contact after outgrowing from the lower layer. On contrary to this statement, our results pointed on the obvious competitiveness in the middle layer, despite the relatively released position of crowns. According to obtained results, mentioned factors prevailed above the direct influence of crown on the production of stem volume, especially when the common beech was evaluated. The trees of upper layer are characterized by the well-developed crowns securing high level of static stability and the regular radial increment (Schütz 2002, Pittner 2012). This statement should be supplemented by obtained knowledge that the crown of tree in the position of middle layer, especially of fir and spruce, can contribute to creation of its stem by up to $60 \%$. The beech-dominated selection forest is characterized by lower basal area when compared to other tree species. The lower interlayer competition resulted in higher variability of the crown sizes in the middle layer. 
The analysis did not confirm the differences between the stem volumes of analyzed species.

In comparison with spruce or fir, the beech needed from four to five times higher volume of crown to produce the stem of the same volume. These results correspond with the findings of Badoux (1949) and Schütz (1998). The mean stem volume of beech reached only $64 \%$ of the spruce stem and $80 \%$ of the mean fir stem volume. The lowest correlation between crown and stem volume was observed for beech comparing to fir and spruce. In spite of the relatively released position of its crowns in the middle layer, it did not resulted into as high increase of stem volume as spruce or fir. According to several authors, the proportion of beech in selection forests should not exceed 10\% of total growing stock due to its high competitive potential which consequently obstructs the achievement and preservation of the selection structure (Balsiger 1925, Schaeffer et al. 1930, Schütz 1989, Duc 2000). Saniga and Vencurik (2008) concluded that beech selection forest growing in their ecological optimum utilizes only $60 \%$ of the productive potential of the site. The low examined correlation between crown and stem volume of beech confirmed this statement. From the point of view of biomass, the selective management system is less suitable for beech dominated stands growing under the conditions of their ecological optimum, especially when compared to spruce and fir in the mountain areas. When we evaluated the growth autonomy through the variation of crown volumes, the spruce and fir seemed to be more conservative. The beech, due to its plagiotropism and high morphological variability of crowns, did not utilize its autonomous position so effectively.

\section{Acknowledgement}

This study was supported by Slovak Science Agency VEGA project No 1/0381/12.

\section{References}

Badoux, E. 1949: L'allure de l'accroissement dans la forêt jardinée. Mitt. Eidgenössische Anstalt forstl. Versuchswes., Bd.26: 7-58.

BAlsiger, R. 1925: Der Plenterwald und seine Bedeutung für die Forstwirtschaft der Gegenwart. Büchler Bern, 107 s.

DitTMAR, O. 1990: Untersuchungen im Buchen -Plenterwald Keula. Forst und Holz, 45 (15): 41-43.
Duc, P. 2000: Zustand, Entwicklung und Pflege des Nachwuchses in Plenterwäldern des Val-de-Travers (Neunburg Jura). Diss. ETH Zürich, $224 \mathrm{~s}$

Gerold, D., Biehl, R., 1992: Vergleich zwischen Buchenplenterwald und Buchenbetriebsklasse. Allgemeine Forst Zeitschrift, 147 (2): 91-94.

JAĎUD̆, J. 2013: Výškové postavenie jedle bielej a smreka obyčajného $v$ štruktúre výberkových lesov [Height position of silver fir and Norway spruce in the selection forest]. In: Baláš, M. Podrázský, V., Kučeravá, B. (eds.): Proceedings of Central European Silviculture, Česká zemědělská univerzita v Praze, 96-105.

JuRČA, J. 1968: Pěstební analytika [Silvicultural analytics]. SPN, Praha, $304 \mathrm{p}$.

Kucbel, S., Vencurik, J. 2007: Model štruktúry smrekového lesa vo vyššom montánnom stupni Oravských Beskýd [Structure model of a Norway spruce forest in high-montane belt of Oravské Beskydy Mts.]. Beskydy 20: 155-160

Leibundgut, H. 1945: Waldbauliche Untersuchungen über den Aufbau von Plenterwäldern. Mitt. Eidg. Anstalt forstl. Versuchswesen, XXIV, 219-296.

Petráš, R., Pajtík, J. 1991: Sústava československých objemových tabuliek dreva [The set of Czechoslovak timber volume tables]. Lesnicky časopis 37: 49-56.

PitTNer, J. 2012: Analýza štrukturálnej diverzity ako kritéria pre hodnotenie ekologickej stability smrekového prírodného lesa $\mathrm{v}$ doline Nefcerka [Analysis of structural diversity as the criterion for stability evaluation of the Norway spruce natural forest in the Nefcerka valley ]. In: Saniga, M., Kucbel, S., Jaloviar, P (eds.): Pestovanie lesa v strednej Európe, p. 86-96

Pretzsch, H., Kahn, M., Grote, R. 1998: Die Fichten-Buchen-Mischbeständen des Sonderforschungsbereiches, Wachstum oder Parasitenabwehr?" im Kranzberger Forst. Forstwissenschaftliches Centralblatt, (117): 241-257.

Pretzch 2010: Gesetzmäßigkeiten der Kronenformentwicklung und Wuchsraumbesetzung. Querschnittsanalyse auf der Basis langfristiger Versuchsflächen. In: Nagel, J. (ed) Deutscher Verband Forstlicher Forschungsanstalten. Sektion Ertragskunde. Jahrestagung 17.-19. Mai 2010, Körbecke am Möhnesee, p. 96-108

SAniga, M., VencuriK, J. 2007: Dynamika štruktúra a regeneračné procesy lesov v rôznej fáze prebudovy na výberkový les v LHC Korytnica [Structural dynamics and regeneration 
processes of the forests of the various stage of conversion to selection structure in LHC Korytnica]. Vedecké štúdie, Zvolen, 83p.

Saniga, M., Vencurik, J. 2008: Dynamika zmien štruktúry a regeneračných procesov bukového výberkového lesa [Structural dynamics and regeneration processes of the beech-dominated selection forest]. Acta facultatis forestalis Zvolen, 50(2): 45-54.

Saniga, M., Balanda, M., Pittner, J., Kucbel, S., Jaloviar, P. 2013: Structural diversity and regeneration patterns of the Norway spruce (Picea abies (L.) Karst) dominated virgin forest in NNR Zadná Pol'ana. Beskydy, 6(2): 127-134.

Schaeffer, A., Gazin, A., D‘Alvemy, A. 1930: Sapinières: Le jardinage par contenance. Presses univ. France, Paris. $100 \mathrm{~S}$.

ScнÜтz, J.-Рн., 1969: Etude de phenoménes de la croisance et hauteur et en diametre du sapin/Abies alba Mill./et de lepicea /Picea abies. Karts./ dans deux peuplements jardines et une foret vierge. Beiheft Schweizerische Zeitschrift für Forstwesen, 44, 115 p.

SснÜтz, J.-Рн. 1975: Dynamique et conditions d'équilibre de peuplements jardinées sur les stations de la hêtraie à sapin. Schweizerische Zeitschrift für Forstwesen, 126: 637-671.

SснÜтz, J.-Рн. 1989: Der Plenterbetrieb. Unterlage zur Vorlesung Waldbau III (Waldverjüngung). Fachbereich Waldbau, ETH, Zürich. 54 p.

SснÜтz, J.-Рн. 1992: Waldbauliche Formen und Grenzen der Plenterung mit Laubbaumarten. Schweizerische Zeitschrift für Forstwesen, 143: 442-460.

SснÜтz, J.-Рн. 1998: Behandlungskonzepte der Buche aus heutiger Sicht. Schweizerische Zeitschrift für Forstwesen, 149(12): 1005-1030.

ScHÜTZ, J.-PH. 2001a: Der Plenterwald und weitere Formen strukturierter und gemischter Wälder. $\mathrm{Pa}-$ rey Bucherverlag, Berlin, $216 \mathrm{p}$.

ScнÜтz, J.-PH. 2001b: Opportunities and strategies of transforming regular forests to irregular forests. Forest Ecology and Management, 151:87-94.

Schüтz, J.-Рн. 2002: Die Plenterung und ihre unterschiedlichen Formen. ETH Zentrum, Zürich, $132 \mathrm{p}$.

SchÜtz, J.-Рн., Pommerening, A. 2013: Can Douglas fir (Pseudotsuga menziesii (Mirb.) Franco) sustainably grow in complex forest structures? Forest Ecology and Management, 303: 101-108.

ŠmeLKo, Š. 2000: Dendrometria [Dendrometry]. Vydavatel'stvo Technickej Univerzity, Zvolen, 399 s.
Teufel, K., Baumgarten, M., Hanewinkel, M., Sauter, H., Wilpert, K., Konold, W., Spiecker, H., 2005: Waldumbau für eine zukunftsorientierte waldwirtschaft. Springer - Verlag, Berlin, 421 p.

UHL, E. 2009: Variabilität des Zuwachsverhaltens unter- und zwischenständiger Bäume nach Freistellung, ein Beitrag zum Baumart Fichte (Picea abisel (L.) Karst.). In: Nagel, J. (ed) Deutscher Verband Forstlicher Forschungsanstalten. Sektion Ertragskunde. Jahrestagung 25.27. Mai 2009, Ascona, p. 61-68.

Utschig, H. 2004: Waldwachstumskundliche Charakterisierung der Tanne. LWF Wissen, Beiträge zur Tanne. Bayerische Landesanstalt für Wald und Forstwirtschaft, 45: 18-23.

Vencurik, J., Kucbel, S. 2008: Hrúbkový prírastoksmreka a jedle vo výberkovom lese Oravských Beskýd [Radial increment of Norwya spruce and silver fir in the selection forests in Oravské Beskydy]. Beskydy 1: 209-214.

Vencurik, J., Kucbel, S., Snopková, Z. 2013: Štruktúra, rast a klimatická senzitivita prirodzenej obnovy smreka obyčajného (Picea abies (L.) Karst.) a jedle bielej (Abies alba Mill.) vo výberkových lesoch severozápadných Karpát [Structure, growth and climate sensitivity of the Norway spruce(Picea abies (L.) Karst.) natural regeneration in the selection forests in Western Carpathians]. Zprávy lesnického výzkumu 58: 123-130.

Yasuda, A., Yoshida, T., Miya, H., Harvey B.D. 2011: An alternative management regime of selection cutting for sustaining structure of mixed forests of northern Japan: a simulation study. Journal of Forest Research, 18: 398-406. 
